\title{
Correlation of the Areal Number Density of Vascular Bundles with the Mechanical Properties of Oil Palm Wood (Elaeis guineensis Jacq.)
}

\author{
Rattana Choowang
}

\begin{abstract}
Currently most of oil palm trunks in Thailand are left on the field to rot or are burnt in the field, not utilized as lumber. To promote such value-added uses, the objective of this study was to characterize the levels and variation within oil palm trunks of their key mechanical properties. In addition, the vascular bundle population was assessed, because this structural characteristic affected density and mechanical properties. The key ones being here were modulus of rupture (MOR), modulus of elasticity (MOE), and hardness. The 25 years old oil palm trunks were selected from a palm plantation in Surat Thani Province, in southern Thailand. The trees were cut down at $500 \mathrm{~mm}$ above ground, cut into dices, then sawn into small pieces in radial direction. Vascular bundle populations and basic densities were determined. Oil palm lumber was sawn from the logs between wood dices, and their mechanical properties were determined. The results indicated that the vascular bundle population density gradually decreased towards the central axis of trunks, and the population density positively correlated with basic density and mechanical properties. This was because the main component of a vascular bundle has fibers with thick cell walls. The data obtained may help select or create products that match the properties of oil palm wood (Elaeis guineensis Jacq.), or contributed to the sorting of wood raw material based on, for example, machine vision.
\end{abstract}

Keywords: oil palm wood, vascular bundle, basic density, mechanical property.

\section{Introduction}

Oil palm trees (Elaeis guineensis Jacq.) are important non-forest agricultural plants that may provide alternative raw material for the wood industries. In Thailand, oil palm plantation areas have expanded from 329,120 hectares in 2003 to 690,560 hectares in 2012, providing palm oil for food and renewable energy. More than $90 \%$ of total plantation area in Thailand is in its southern peninsular part, especially in Surat Thani, Krabi, and Chumphon provinces (Office of Agricultural Economics 2012). When the oil palm trees are past their economic life at 25 to 30 years old, the trunks are usually in the range of 15 to 18 meters in height and 45 to 60 centimeters in diameter. They are felled to make room for replanting, and normally left to rot or burnt down in the field (Katemanee 2006). Presently, oil palm trunks are not a raw material for wood industries, due to low density and poor mechanical properties compared to other commercial wood species from agro-forestry, such as rubberwood (Ratnasingam and Loras 2010). An oil palm trunk contains $31.70 \%$ to $47.30 \%$ cellulose, $21.20 \%$ to $34.40 \%$ hemicelluloses, and $18.40 \%$ to $29.60 \%$ lignin (Kaida et al. 2009; Yuliansyah et al. 2010; Chin et al. 2010; Verman and Saka 2011). The middle and core parts of trunk are $12.19 \%$ to $17.17 \%$ starch and it has high free sugar in sap (Yamada et al. 2010; Hashim et al. 2011). Especially in Thailand, these glucose based reserves in oil palm trunks have been studied for fermentation to produce bio-ethanol and hydrogen renewable energy (Punsuvon et al. 2005; Hniman et al. 2011). However, the oil palm wood taken from the bottom peripheral zone of stem can be used in furniture and in non-structural construction components (Ratnasingam and Loras 2010). Previous studies reported that the utilization of oil palm wood as lumber or laminated wood was difficult, because the product quality was affected by variation of physical and mechanical properties within trunk (Ratnasingam et al. 2008; Feng et al. 2011). The oil palm tree is a monocotyledon, and its main structure consists of vascular bundles embedded in parenchyma cells. The vascular bundles are the mechanical support and serve as a conduits for the transportation of water and nutrients in the trunk. Their number density per volume decreases towards the axial center, and increases in the trunk from the ground towards top of the tree (Erwinsyah 2008). Therefore, the objective of this study was to clarify the relation of vascular bundle population density with basic density and some mechanical properties of oil palm wood. The results may help rapidly estimate the mechanical properties of oil palm wood samples, and help with such selective use of oil palm wood that the quality control problems mentioned above are ameliorated.

\section{Materials and Methods}

Oil palm trees of 25 years of age were harvested from a local plantation in Surat Thani Province, in southern Thailand. The trees were cut down at $500 \mathrm{~mm}$ above ground, and cut into $60 \mathrm{~mm}$ thickness dices alternating with $1 \mathrm{~m}$ logs, as shown in Fig. 1. The oil palm dices were sawn into long pieces in the radial direction from pith to bark of trunk, $60 \mathrm{~mm}$ wide in tangential, and stored in plastic bags to avoid loss of moisture. The vascular bundle population density and the basic density were determined from these pieces. The logs between wood dices were sawn to lumber for mechanical property testing. 


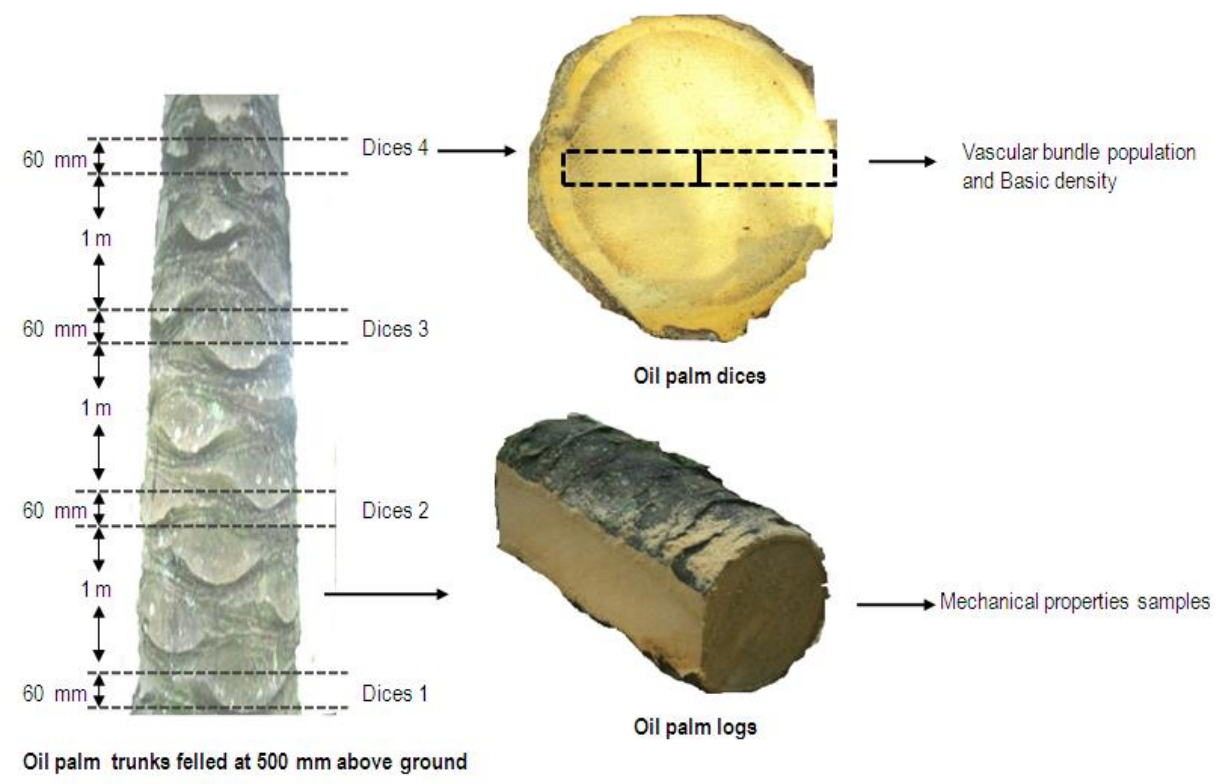

Figure 1. A schematic illustration of conversion of an oil palm trunk to the samples studied for vascular bundle population density, basic density, and mechanical properties.

The green oil palm woods which cut from dices were photographed from trunk axis to bark, using a stereo microscope, and the vascular bundles were counted from the images. Then, the same wood samples were cut to small $20 \mathrm{~mm}$ (tangential) $\times 20 \mathrm{~mm}$ (radial) $\times 25 \mathrm{~mm}$ (longitudinal) pieces to determine basic density profile, similarly from axis to bark. These green samples were measured in radial, tangential, and longitudinal directions with a digital caliper to the nearest $0.01 \mathrm{~mm}$, weighed to nearest $0.01 \mathrm{~g}$, and oven-dried at $103+2^{\circ} \mathrm{C}$ to constant weight. Finally, the oven-dry weights to the nearest $0.01 \mathrm{~g}$ were determined after cooling in desiccator. The basic density was calculated from the ratio of the oven-dry weight $(\mathrm{g})$ and volume in green condition $\left(\mathrm{cm}^{3}\right)$.

Oil palm logs were sawn into $50 \mathrm{~mm}$ thick lumber using a polygon sawing pattern (Bakar et al. 2006), to separate the wood to inner, middle, and outer zones, that match the distribution of vascular bundles. The green lumber was air dried to a moisture content of $8-12 \%$, and then planed and cut to $20 \mathrm{~mm}$ (tangential) $\times 20 \mathrm{~mm}$ (radial) x $300 \mathrm{~mm}$ (longitudinal) samples for static bending (modulus of rupture, MOR and modulus of elasticity, MOE), and to 20 $\mathrm{mm}$ (tangential) $\times 20$ (radial) $\times 60 \mathrm{~mm}$ (longitudinal) samples for Janka type hardness test. All samples were conditioned in ambient $20^{\circ} \mathrm{C}$ temperature and $65 \%$ relative humidity until equilibrium moisture content, before the mechanical properties were determined using a universal testing machine. The testing of mechanical properties followed BS 373 standard (BS 373 1957) with slight modifications.

\section{Results and Discussion}

Microphotography of wood anatomy, using a stereo microscope, showed that the vascular bundles were unevenly distributed across the trunk, and surrounded by parenchyma cells. The population density increased radially from $23 \mathrm{Vp} / \mathrm{cm}^{2}$ at the axial center to $115 \mathrm{Vp} / \mathrm{cm}^{2}$ near bark, and varied by height along the trunk. The graph in Fig. 2 indicates a close relationship between this number density and basic density that increased from $0.11 \mathrm{~g} / \mathrm{cm}^{3}$ at the center to $0.40 \mathrm{~g} / \mathrm{cm}^{3}$ near bark. The vascular bundles were mostly fibers with thick cell walls, and this thickness was $8.08 \mu \mathrm{m}$ at $2 \mathrm{~m}$ height. In addition, the thin walled parenchyma cells have a higher moisture content (Erwinsyah 2008; Fatimah et al. 2012). Therefore, the ovendry weight of oil palm wood at high percentage of vascular bundles was high after they loosed the water in cell. This was the reason for the strong correlation with basic density.

The results in Fig. 3 showed that the overall mechanical properties of oil palm wood improve outwards from the axis. The average modulus of rupture, modulus of elasticity, and hardness of outer zone had the highest values at $26.20 \mathrm{MPa}, 4861.49 \mathrm{MPa}$, and $1342.10 \mathrm{~kg}$, respectively. Those properties were, in the same order, decreased to $8.76 \mathrm{MPa}, 1711.39 \mathrm{MPa}$, and $486.10 \mathrm{~kg}$ for the middle zone, and further to $5.73 \mathrm{MPa}, 516.53 \mathrm{MPa}$, and $223.60 \mathrm{~kg}$ for the inner zone. The areal number density of vascular bundles in the outer zone ranged from $68 \mathrm{Vp} / \mathrm{cm}^{2}$ to $115 \mathrm{Vp} / \mathrm{cm}^{2}$, and in the middle and inner zones from 44 $\mathrm{Vp} / \mathrm{cm}^{2}$ to $58 \mathrm{Vp} / \mathrm{cm}^{2}$ and from $23 \mathrm{Vp} / \mathrm{cm}^{2}$ to $40 \mathrm{Vp} / \mathrm{cm}^{2}$, respectively. 
a)

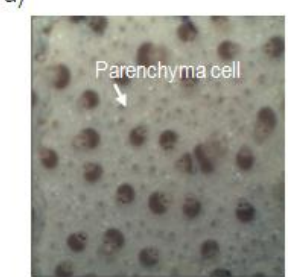

b)

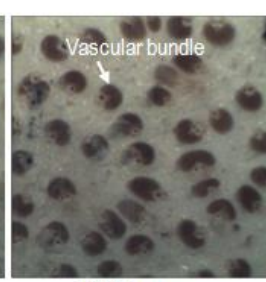

Middle zone

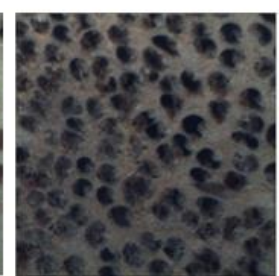

Outer zone

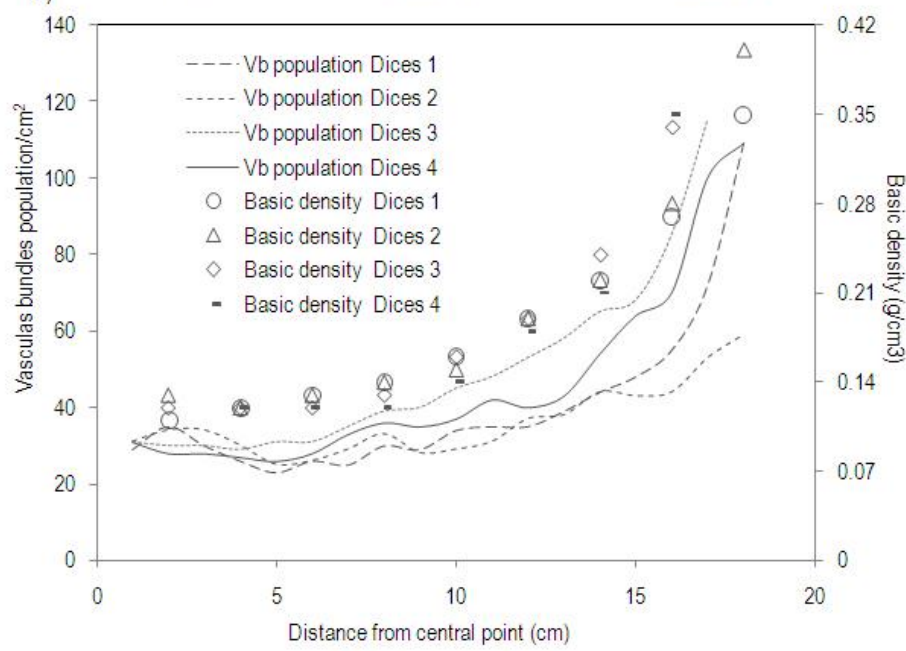

Figure 2. Microphotographs of inner, middle, and outer zones (a), and the relationship of radial profiles of vascular bundle density and basic density of oil palm wood, at various heights along the trunk (b).

a)

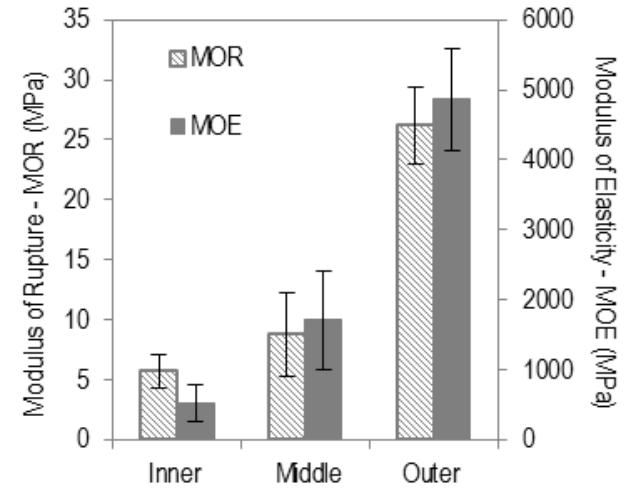

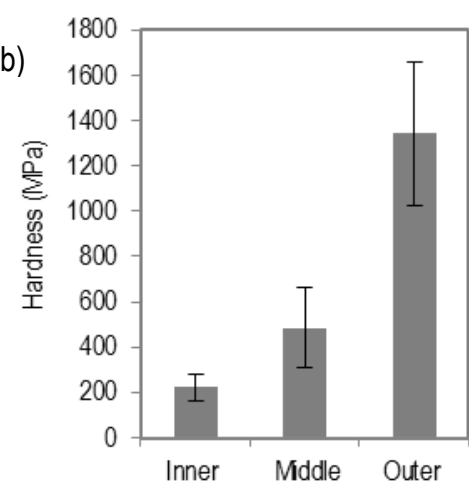

Figure 3. Modulus of rupture, Modulus of elasticity (a), and Hardness (b) of oil palm wood in inner, middle, and outer zones of the trunk.

\section{Conclusions}

The basic density and mechanical properties (static bending and hardness) of oil palm wood strongly correlated positively with the areal number density of vascular bundles. The data suggest that quick estimation of oil palm wood mechanical characteristics could be partly based on this areal number density. Such characterization could assist in rapid selection and avoiding destructive testing of the best parts of oil palm trunks for specific applications, for example by sorting based on machine vision. 


\section{Acknowledgments}

The author is grateful for the support of Prince of Songkla University, Surat Thani Campus Research Fund. Assoc. Prof. Seppo Karrila, Ph.D. provided helpful comments on this manuscript.

\section{References}

Bakar, E.S.; F. Febrianto; I. Wahyudi; and Z. Ashari. 2006. Polygon Sawing: An Optimum Sawing Pattern for Oil Palm Stems. J Biol Sci. 6(4): 744-749.

British Standard. 1957. Methods of Testing Small Clear Specimens of Timber, BS 373, British Standards House, 2 Park ST., London, W.1

Chin, K.L.; P.S. H'ng; L.J. Wong; B.T. Tey; and M.T. Paridah. 2010. Optimization Study of Ethanolic Fermentation from Oil Palm Trunk, Rubberwood and Mixed Hardwood Hydrolysates using Saccharomyces cervisian. Biores Technol. 101: 3287-3291.

Erwinsyah V. 2008. Improvement of Oil Palm Wood Properties using Bioresin [PhD thesis]. Institit fur Forstntzung und Forsttechnik Fakultat fur Foest-,Geound Hydrowissenschaften: Technische Universitat Dresden.

Feng, L.Y.; P.M. Tahir; and Y.B. Hoong. 2011. Density Distribution of Oil Palm Stem Veneer and Its Influence on Plywood Mechanical Properties. J Appl Sci. 11(5): 824-831.

Hashim, R.; N. Said; J. Lamaming; M. Baskaran; 0. Sulaiman; M. Sato; S. Hiziroglu; and T. Sugimoto. 2011. Influence of Press Temperature on the Properties of Binderless Particleboard Made from Oil Palm Trunk. Materials \& Design 32: 2520-2525.

Hniman, A.; S. O-Thong; and P. Prasertsan. 2011. Developing a Thermophilic Hydrogen Producing Microconsortia from Geothermal Spring for Efficient Utilization of Xylose and Gucose Mixed Substrates and Oil Palm Trunk Hydrolysate. Int J Hydro Energy. 36: 8785-8793.

Katemanee, A. 2006. Appropriate Technology Evaluation for Oil Palm by Products Utilization in Krabi Province [M.S. thesis]. Faculty of Graduate Studies, Mahidol University $89 \mathrm{p}$.

Kaida, R.; T. Kaku; K. Baba; M. Oyadomari; T. Watanabe; S. Hartati; O. Sudarm; and Y. Hayashi. 2009. Emzymatic Saccharification and Ethanol Production of
Acacia mangium and Paraserianthes falcataria Wood and Elacis guineensis Trunk. J Wood Sci. 55: 381386.

Office of Agricultural Economic. 2012. Agricultural Statistics of Thailand. Bangkok, Thailand. $136 \mathrm{p}$.

Punsuvon, V.; W. Anpanurak; P. Vaithanomsat; and N. Tungkananurak. 2005. Fractionation of Chemical Components of Oil Palm Trunk by Steam Explosion. Proceeding of $31^{\text {st }}$ Congress on Science and Technology of Thailand; 2005 October 18-20; Suranaree University of Technology.

Rarnasingam, J.; T.P. Ma; M. Manikam; and S.R. Farrokhpayam. 2008. Evaluating the Machining Characteristics of Oil Palm Lumber. Asian J. of Applied Sciences 1(4): 334-340.

Ratnasingam, J. and F. Loras. 2010. Static and Fatigue Strength of Oil Palm Wood Used in Furniture. J Appl Sci. 10(11): 986-990.

Sitti Fatimah, M.R.; O. Sulaiman; R. Hashim; T. Arai; A. Kosugi; H. Abe; Y. Murata; and Y. Mori. 2012. Characterization of Parenchyma and Vascular Bundle of Oil Palm Trunk as Function of Storage Time. Lignocellulose 1(1): 33-44.

Verman, M. and A.A. Saka. 2011. Comparative Study of Oil Palm and Japanese beech on their Fractionation and Characterization as Treated by Supercritical Water. Waste Biomass Valor. 2: 309-315.

Yamada, H.; R. Tanaka; O. Sulaiman; R. Hashim; Z.A.A. Hamid; M.K.A. Yahya; A. Kosugi; T. Arai; Y. Murata; S. Nirasawa; K. Yamamoto; S. Ohara; M.N.M. Yusuf; W.A. Ibrahim; and Y. Mori. 2010. Oil Palm Trunk: A Promising Source of Sugar for Bioethanol Production. Biomass \& Bioenergy 34: 1608-1613.

Yuliansyah, A.T.; T. Hirajima; S. Kumagai; and K. Sasaki. 2010. Production of Solid Biofuel from Agricultural Wastes of the Palm Oil Industry by Hydrothermal Treatment. Waste Biomass Valor. 1: 395-405.

\section{Rattana Choowang}

Wood Sciences and Industry Technology Research Unit, Faculty of Science and Industrial Technology,

Prince of Songkla University, Surat Thani Campus, Mueang, Surat Thani 84000, Thailand.

E-mail : rattana.ch@psu.ac.th 